OPEN ACCESS

\title{
High Rate Lithium Ion Battery with Niobium Tungsten Oxide Anode
}

To cite this article: Yumi Kim et al 2021 J. Electrochem. Soc. 168010525

View the article online for updates and enhancements.

\section{Discover the EL-CELL potentiostats}

- Fully independent test channels with Pstat / GStat / EIS

- Optionally with integrated temperature controlled cell chamber

- Unique Connection Matrix: Switch between full-cell and half-cell control at runtime

www.el-cell.com +49 (0) 4079012734 sales@el-cell.com

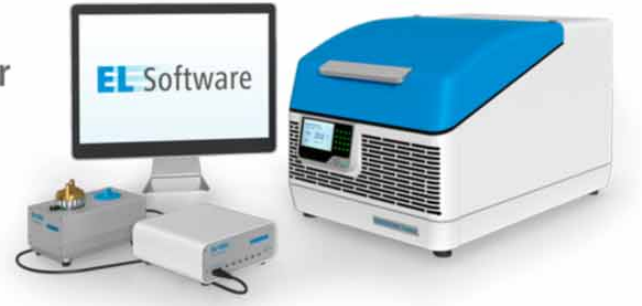




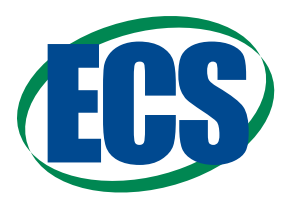

\title{
High Rate Lithium Ion Battery with Niobium Tungsten Oxide Anode
}

\author{
Yumi Kim, ${ }^{1}$ (i) Quentin Jacquet, ${ }^{1}$ (i) Kent J. Griffith, ${ }^{2, *}$ (i) Jeongjae Lee, ${ }^{1}$ Sunita Dey, ${ }^{1}$ \\ Bernardine L. D. Rinkel, ${ }^{1}$ and Clare P. Grey ${ }^{1, * *, z}$ \\ ${ }^{1}$ Department of Chemistry, University of Cambridge, Cambridge, CB2 1EW, United Kingdom \\ ${ }^{2}$ Departments of Chemistry and Materials Science and Engineering, Northwestern University, Evanston, Illinois 60208, \\ United States of America
}

\begin{abstract}
Highly stable lithium-ion battery cycling of niobium tungsten oxide $\left(\mathrm{Nb}_{16} \mathrm{~W}_{5} \mathrm{O}_{55}, \mathrm{NWO}\right)$ is demonstrated in full cells with cathode materials $\mathrm{LiNi}_{0.6} \mathrm{Mn}_{0.2} \mathrm{Co}_{0.2} \mathrm{O}_{2}$ (NMC-622) and $\mathrm{LiFePO}_{4}$ (LFP). The cells show high rate performance and long-term stability under $5 \mathrm{C}$ and $10 \mathrm{C}$ cycling rates with a conventional carbonate electrolyte without any additives. The degradation of the cell performance is mainly attributed to the increased charge transfer resistance at the NMC side, consistent with the ex situ XRD and XPS analysis demonstrating the structural stability of NWO during cycling together with minimal electrolyte decomposition. Finally, we demonstrate the temperature-dependent performance of this full cell at 10,25 and $60^{\circ} \mathrm{C}$ and confirm, using operando $\mathrm{XRD}$, that the structural change of the NWO material during lithiation/de-lithiation at $60{ }^{\circ} \mathrm{C}$ is very similar to its behaviour at $25^{\circ} \mathrm{C}$, reversible and with a low volume change. With the merits of high rate performance and long cycle life, the combination of NWO and a commercial cathode represents a promising, safe battery for fast charge/discharge applications.

(C) 2021 The Author(s). Published on behalf of The Electrochemical Society by IOP Publishing Limited. This is an open access article distributed under the terms of the Creative Commons Attribution Non-Commercial No Derivatives 4.0 License (CC BYNC-ND, http://creativecommons.org/licenses/by-nc-nd/4.0/), which permits non-commercial reuse, distribution, and reproduction in any medium, provided the original work is not changed in any way and is properly cited. For permission for commercial reuse, please email: permissions@ioppublishing.org. [DOI: 10.1149/1945-7111/abd919]
\end{abstract}

Manuscript submitted October 17, 2020; revised manuscript received December 14, 2020. Published January 15, 2021. This was paper 381 presented at the Atlanta, Georgia, Meeting of the Society, October 13-17, 2019.

Supplementary material for this article is available online

The growing global energy demand, together with the quest for clean and renewable sources of energy, drives research into Li-ion batteries with high energy density and high rate performance. ${ }^{1-3}$ In many portable electronics and electric vehicles, fast charging and high power density are two of the key requirements. ${ }^{4-6}$ In this regard, $\mathrm{LiFePO}_{4}$ (LFP) has been extensively used as a stable cathode material allowing for high currents in a full cell; it however exhibits a lower working voltage (vs $\mathrm{Li}$ ) and practical capacity than $\mathrm{Ni}$-rich cathodes such as $\mathrm{LiNi}_{0.6} \mathrm{Mn}_{0.2} \mathrm{Co}_{0.2} \mathrm{O}_{2}$ (NMC-622). ${ }^{7-10}$ On the anode side, graphite is used commercially due to its low cost, wide availability and low delithiation voltage (vs Li); however, it has electrolyte stability issues at low voltages resulting in the formation of a passivating layer. ${ }^{11,12}$ This surface-electrolyte interphase (SEI) layer is known to be an essential component for graphite anodes; however, it consumes $\mathrm{Li}^{+}$during formation, lowering the initial coulombic efficiency of the cell. Moreover, graphite has the serious issue of Li plating at high rates and/or low temperatures leading to the formation of dendrites negatively impacting the cycle life, rate capability and safety of the cell. $\mathrm{Li}_{4} \mathrm{Ti}_{5} \mathrm{O}_{12}$ (LTO), having a higher working voltage $(1.55 \mathrm{~V}$ vs $\mathrm{Li})$ hence reduced SEI formation and dendrite growth, is commonly suggested as a promising candidate for high power applications. However, it needs to be nanosized to access high rates, leading to a low volumetric energy density of LTO-based cells, and problematic evolution of $\mathrm{H}_{2}$ and $\mathrm{CO}_{2}$ gases upon cycling. ${ }^{13-16}$ Clearly, novel anode materials with high rate performance are needed for safe Li-ion cells with high energy and power densities.

Recently, our group has reported that $\mathrm{Nb}_{16} \mathrm{~W}_{5} \mathrm{O}_{55}$ (NWO) which crystallizes in a $\mathrm{ReO}_{3}$ block-type structure, featuring $2 \mathrm{D}$ tunnels suitable for $\mathrm{Li}$ conduction shows promising performance for highrate lithium-ion energy storage even with micro-sized particles. ${ }^{17}$ Many other studies of compounds having different stoichiometries but similar structural motifs have also shown excellent high rate performance in half-cell configurations and for electrodes having a high conductive carbon content $(>10 \%)$ and low loading $\left(<2 \mathrm{mg} \mathrm{cm}^{-2}\right) \cdot{ }^{18-21}$ Here we

\footnotetext{
*Electrochemical Society Member.

**Electrochemical Society Fellow.

${ }^{\text {zE} E-m a i l: ~ c p g 27 @ c a m . a c . u k ~}$
}

present the full cell performance of more practical electrodes of NWO in combination with two commercial cathode materials for high rate $\mathrm{Li}$ ion batteries: LFP and NMC.

\section{Experimental}

Electrode preparation.- NWO powder was synthesized as previously reported in the literature. ${ }^{17}$ NMC-622 (Targray) and a commercial source of carbon-coated LFP with 0.5 um particle size were used as cathodes (Fig. S1 available online at stacks.iop.org/ JES/168/010525/mmedia). The XRD analysis of all active materials confirm that they are phase pure as shown in Fig. S2. High loadings electrodes were prepared mixing Super P carbon (TIMCAL) and polyvinylidene fluoride (PVdF; Kynar) dispersed in $\mathrm{N}$-methyl-2pyrrolidone. All slurries were composed of $90 \%$ active material, $5 \%$ super $\mathrm{P}$ and $5 \% \mathrm{PVdF}$ binder, and the mixing was conducted with a Thinky Mixer 250. The NMC and LFP electrodes were dried in an oven at $80{ }^{\circ} \mathrm{C}$ for $2 \mathrm{~h}$ in a dry room, and the NWO electrodes were dried in an oven at $60{ }^{\circ} \mathrm{C}$ overnight under ambient atmosphere. All electrodes were calendared at room temperature and the resulting electrode porosities were in the range of $35 \%-45 \%$. The electrodes loadings were $8.0-8.3 \mathrm{mg} \mathrm{cm}^{-2}$ (NMC), 8.4-8.7 $\mathrm{mg} \mathrm{cm}^{-2}$ (LFP) and 8.8-9.4 $\mathrm{mg} \mathrm{cm}^{-2}$ (NWO) with $1 \mathrm{~cm}^{2}$ electrode size. Low loading electrodes were prepared in a similar fashion but with a different composition namely having 10\% Li250 carbon (Denka), 10\% PVdF (Kynar) dispersed in $\mathrm{N}$-methyl-2-pyrrolidone, and $80 \%$ of active material. The resulting active material loading were $4.0 \mathrm{mg} \mathrm{cm} \mathrm{cm}^{-2}$ for NMC, $3.8 \mathrm{mg} \mathrm{cm}^{-2}$ for LFP and $4.4 \mathrm{mg} \mathrm{cm}^{-2}$ for NWO.

Electrochemical characterization.-All electrochemical measurements were evaluated with 2032-type stainless steel coin cells. Prepared cathode and anode electrodes were dried at $100{ }^{\circ} \mathrm{C}$ for $3 \mathrm{~h}$ under vacuum, then transferred into an argon-filled glove box (MBraun) without exposure to air. Full cells were assembled in the glove box with LP30 electrolyte (Sigma-Aldrich, battery grade), which is composed of $1.0 \mathrm{M}$ lithium hexafluorophosphate $\left(\mathrm{LiPF}_{6}\right)$ in ethylene carbonate (EC): dimethyl carbonate (DMC) $(1: 1 \mathrm{v} / \mathrm{v})$. A polyethylene separator (Toray) was used after drying at $40{ }^{\circ} \mathrm{C}$ for $2 \mathrm{~h}$ under vacuum. For electrolyte analyses, glass fiber filter paper (Whatman, GE) was used as the separator. The filter was also dried 
a

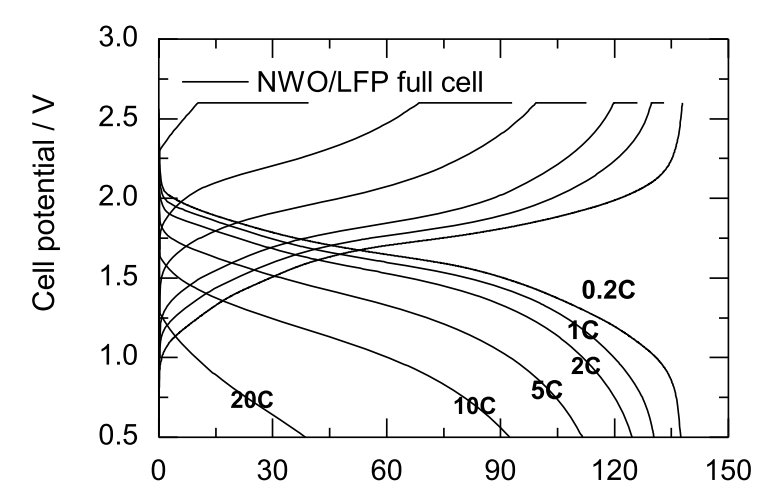

$\mathbf{C}^{-}$

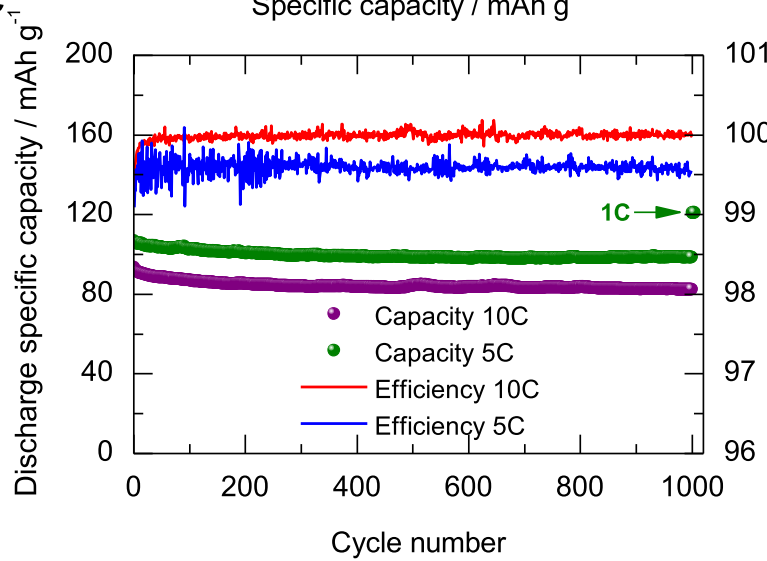

b
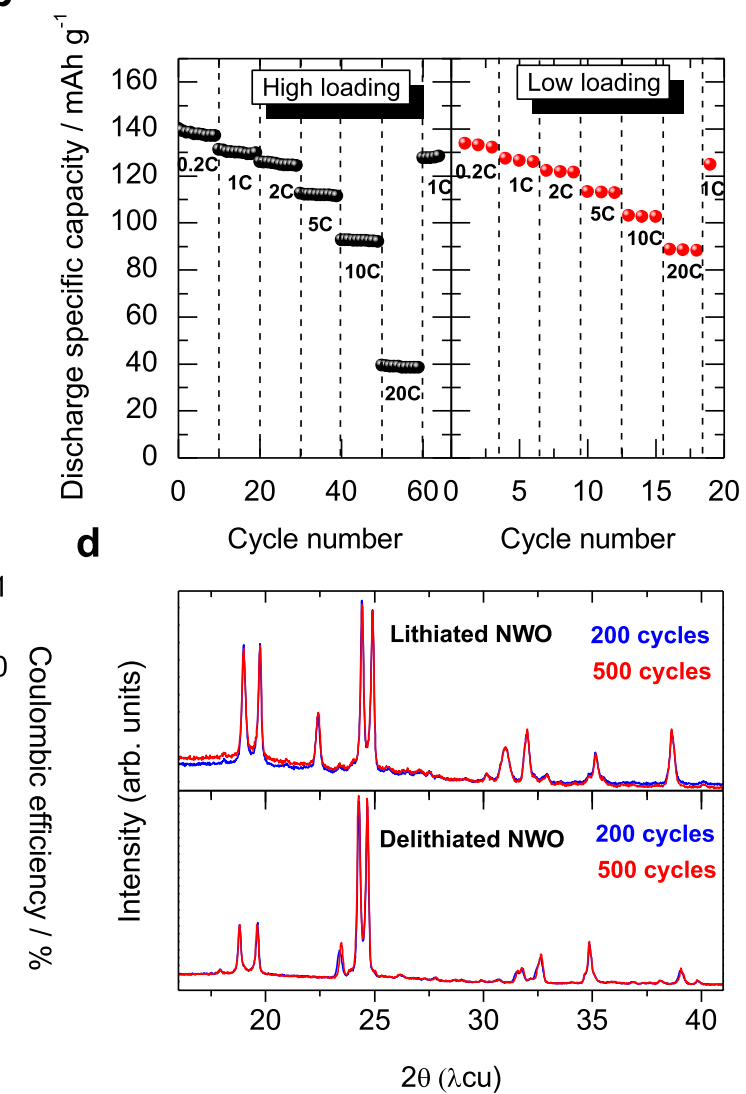

Figure 1. (a) Cell voltage profiles of the high loading NWO/LFP full cell at $0.2 \mathrm{C}, 1 \mathrm{C}, 2 \mathrm{C}, 5 \mathrm{C}, 10 \mathrm{C}$ and $20 \mathrm{C}$, (b) Rate performance of the high loading and low loading NWO/LFP full cells and (c) Discharge capacity and coulombic efficiency (C.E.) plots from long-term cycling of the high loading NWO/LFP cell operated at $25{ }^{\circ} \mathrm{C}$ at $5 \mathrm{C}$ and $10 \mathrm{C}$ (d) XRD patterns of ex situ NWO electrodes cycled in a LFP/NWO full cell at $5 \mathrm{C}$ for 200 and 500 cycles and stopped after charge (lithiated NWO) and discharge (delithiated NWO).

at $150{ }^{\circ} \mathrm{C}$ under vacuum in a drying oven (Buchi). For half cells, $\mathrm{Li}$ metal chip (250 $\mu \mathrm{m}$, PI-KEM), LP30 electrolyte and glass fiber filter were used as the counter electrode, electrolyte and separator, respectively. Galvanostatic electrochemical tests were conducted at various current densities by using a galvanostat/potentiostat (BioLogic) in a temperature-controlled oven at 10,25 and $60{ }^{\circ} \mathrm{C}$. All cells had a negative-to-positive capacity ratio of $1.1-1.2$, which is calculated based on the practical capacities of the active materials, i.e. $171.3 \mathrm{mAh}$ $\mathrm{g}^{-1}$ for NWO, $175 \mathrm{mAh} \mathrm{g}^{-1}$ for NMC and $165 \mathrm{mAh} \mathrm{g}^{-1}$ for LFP. Full cell capacities in this study are calculated by active material mass of the cathode. In full cell tests, charge was performed under constant current and constant voltage mode $(\mathrm{CC} / \mathrm{CV}$, with the $\mathrm{CV}$ step limited by specific current to $>\mathrm{C} / 10$ ) and discharge was operated under constant current (CC) mode. For symmetrical cell tests, two full cells having the same loading were operated at $0.2 \mathrm{C}$, and impedance was measured at $2.0 \mathrm{~V}$ during the charging step. Frequencies from $1 \mathrm{MHz}$ to $100 \mathrm{mHz}$ were scanned with an applied amplitude of $10 \mathrm{mV}$. Afterwards, cells were disassembled in the glove box, and two symmetric cells were assembled with fresh LP30 electrolyte. Electrochemical impedance was measured again on the symmetric cells under the same conditions. For half cells, working voltages were $1-3 \mathrm{~V}$ vs $\mathrm{Li}^{-} \mathrm{Li}^{+}(\mathrm{NWO}), 3.0-4.2 \mathrm{~V}$ vs $\mathrm{Li}^{-} \mathrm{Li}^{+}$(NMC), and $2.8-4.0 \mathrm{~V}$ vs $\mathrm{Li} / \mathrm{Li}^{+}$(LFP).

Characterization of electrodes.-For characterization, ex situ samples were prepared as follow: cells were disassembled and rinsed with DMC, then dried in the glovebox pre-chamber under vacuum. Electrode microstructures were analyzed by scanning electron microscopy (MIRA3, TESCAN) at $5.0 \mathrm{kV}$ with secondary electron detection. Electron microscopy images of the pristine electrodes of NWO, NMC and LFP are shown Fig. S1. X-ray diffraction patterns of pristine and cycled electrodes were obtained in Bragg-Brentano geometry (Empyrean, Panalytical) at ambient temperature with a $\mathrm{Cu}-\mathrm{K} \alpha$ source. The operando XRD measurement at high temperature was performed in the same instrument using a home-made cell with a Be window and heating bars. The scan time was $10 \mathrm{~min}$. Lattice parameters, phase and purity of the material were determined by Rietveld refinement (or Lebail on the NWO material due to its large unit cell) using the FullProf software. ${ }^{22} \mathrm{X}$-ray photoelectron spectroscopy (XPS) was carried out with a Thermo Fisher Scientific instrument with a monochromated Al-K $\alpha$ X-ray source $(h \nu$ of $1468.7 \mathrm{eV})$. Samples were adhered to conductive carbon film taped onto an airtight transfer chamber equipped with an X-ray-transparent window.

Characterization of electrolyte.-For electrolyte analyses, the glass fiber separator was extracted from cell and soaked in $0.75 \mathrm{ml}$ of DMSO-d $_{6}$ (Sigma-Aldrich, 99.9 atom\% D, 99\% CP) for 5 min, after which the solution was transferred into an air-tight J-Young tube. ${ }^{1} \mathrm{H}$, ${ }^{19} \mathrm{~F}\left\{{ }^{1} \mathrm{H}\right\}$ and ${ }^{31} \mathrm{P}\left\{{ }^{1} \mathrm{H}\right\}$ NMR spectra were recorded on a Bruker Avance III HD $500 \mathrm{MHz}$ Smart Probe spectrometer using a BBO probe. ${ }^{1} \mathrm{H}$ decoupling was achieved using the Waltz-16 decoupling sequence. ${ }^{1} \mathrm{H}$ NMR spectra were internally referenced to DMSO- $\mathrm{d}_{6}$ at $2.50 \mathrm{ppm}$ and the ${ }^{19} \mathrm{~F}$ and ${ }^{31} \mathrm{P}$ NMR spectra were internally reference to $\mathrm{LiPF}_{6}$ at $-74.5 \mathrm{ppm}$ and $-145 \mathrm{ppm}$, respectively.

\section{Results and Discussion}

NWO/LFP full cell at room temperature.-To assess the stability of NWO anodes upon cycling, LFP cathodes, which are known to show stable cycling without significant degradation, were initially used in a full cell (1.54 mAh capacity). Figure 1a shows 
a
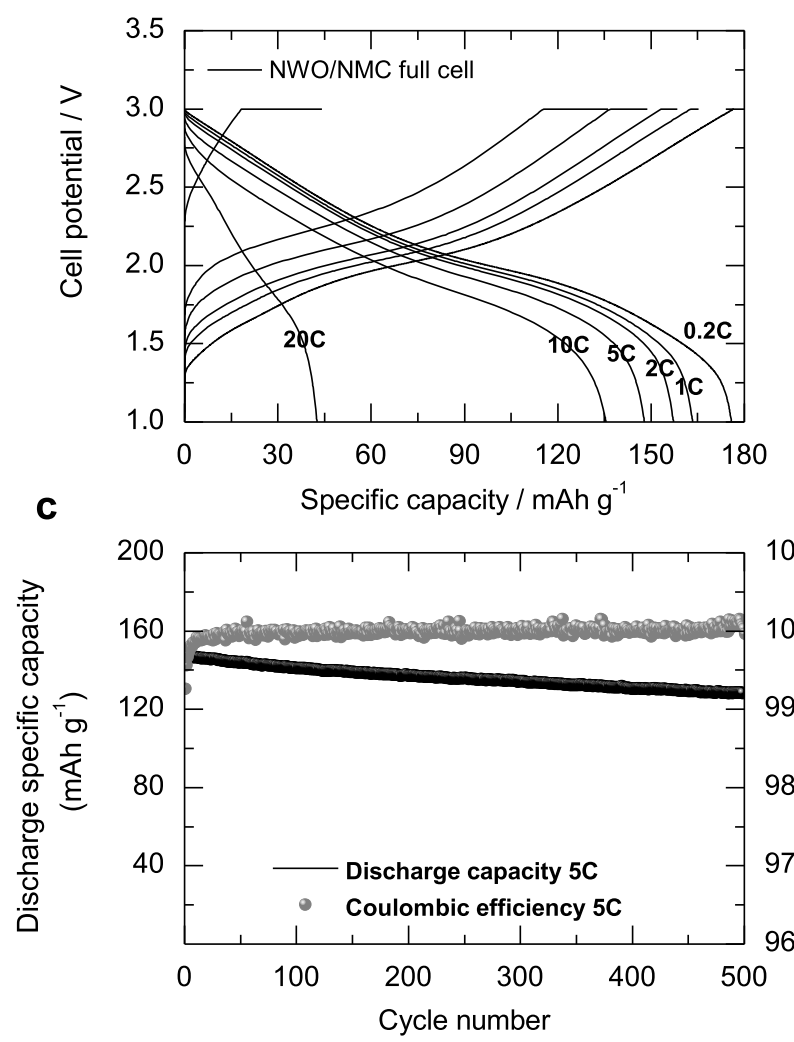

b

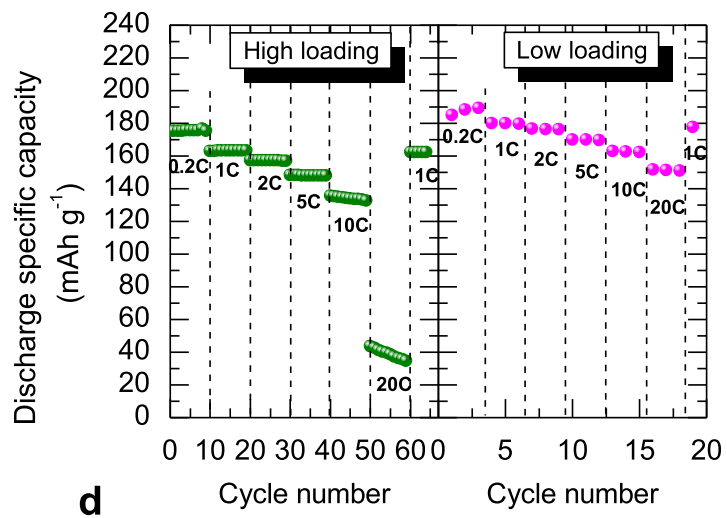

101

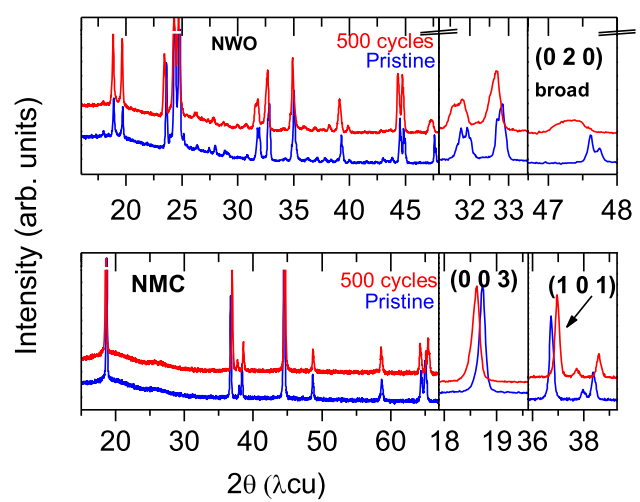

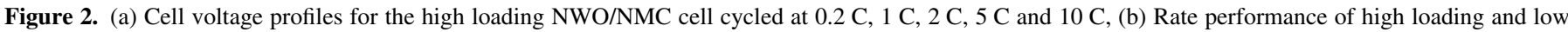

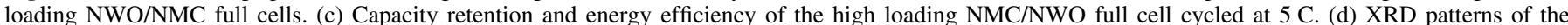

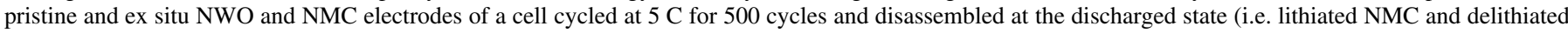

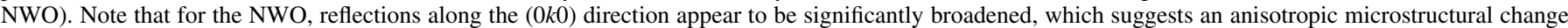
of particles.

the voltage profiles of the charge and discharge reaction, and the operating window was determined to be between 0.5 to $2.6 \mathrm{~V}$, with $>90.8 \%$ of the capacity being obtained between 1 and $2 \mathrm{~V}$ on discharge at $\mathrm{C} / 5\left(34.2 \mathrm{~mA} \mathrm{~g}^{-1}\right)$. Figure $1 \mathrm{~b}$ shows the discharge capacity as a function of C-rate at $25^{\circ} \mathrm{C}$, the cells showing discharge capacities of $140 \mathrm{mAh} \mathrm{g}^{-1}$ at $0.2 \mathrm{C}$ and $130,125,112,92$ and $39 \mathrm{mAh} \mathrm{g}^{-1}$ at $1 \mathrm{C}, 2 \mathrm{C}, 5 \mathrm{C}, 10 \mathrm{C}$ and $20 \mathrm{C}$, respectively. The cell recovers a capacity of $128 \mathrm{mAh} / \mathrm{g}$ when the $\mathrm{C}$-rate is returned to $1 \mathrm{C}$. The discharge capacity of this NWO/LFP cell at $20 \mathrm{C}$ is significantly reduced, but could be improved by optimizing the electrode structure as suggested by the $\mathrm{C}$-rate performance of lower electrode loadings which delivers up to $89 \mathrm{mAh} \mathrm{g}^{-1}$ at $20 \mathrm{C}$ (Fig. 1b).

Based on this result, the long-term cycling performance of $\mathrm{NWO} /$ LFP cells was investigated for 1000 cycles at a rate of $5 \mathrm{C}$ and $10 \mathrm{C}$ over the full state-of-charge range. At $5 \mathrm{C}, 92.1 \%$ of capacity retention is observed at 1000 cycles, $3.9 \%$ of the original capacity being lost after 100 cycles and $7.9 \%$ at 500 cycles (Fig. 1c). However, less than $0.01 \%$ capacity loss was observed during the final 500 cycles. In other words, after the initial 500 cycles, only $0.00002 \%$ of the capacity decays per cycle. The capacity retention was further checked by cycling the cell at $1 \mathrm{C}$ after the initial 1000 cycles, the cell recovered $96.5 \%$ of the original capacity. Full cell operation at $10 \mathrm{C}$ demonstrated capacity losses of $6.8 \%, 9.2 \%$ and $11.1 \%$ for 100,500 and 1000 cycles, respectively; the corresponding coulombic efficiency remained constant at $99.99 \%$ up to 1000 cycles. Note that XRD patterns of the NWO electrode after 200 and 500 cycles at $5 \mathrm{C}$ show that the crystal structure is retained with no peak broadening and signs of amorphization (Fig. 1d). These results clearly illustrate the excellent long-term cyclability of NWO/ LFP full cells up to 1000 cycles, which directly demonstrates the applicability of NWO materials as anodes in Li-ion full cells.
At this stage we compare these cell performances with LTO/LFP full cells since LTO has a similar working voltage to NWO but is already commercialized in battery technology. Pohjalainen et al. have reported LTO/LFP full cells with a discharge capacity fade of $5 \%$ under $1 \mathrm{C}$ for 300 cycles. $^{23}$ Wang et al. have reported that a carbon-modified LFP and unmodified LTO anode exhibited capacity loss of $11 \%$ at $0.5 \mathrm{C}$ over more than 1200 cycles. $^{24}$ However, in another example, cells constructed with submicron spherical secondary LTO particles and commercial LFP achieved excellent performances $(2 \%$ capacity loss for 8000 cycles at $30 \mathrm{C}){ }^{25}$ The present high loading NWO/LFP cells, without optimization of particle size, morphology, binder chemistry or electrolyte composition, shows comparable or better cycle life at higher C-rates than reported for many of these LTO/LFP cells. These results are extremely promising and call for further optimization to investigate the full potential of this chemistry.

NWO/NMC full cell at room temperature.-To further increase the energy density of the full cell, the NWO anode was tested against an NMC-622 cathode, which has emerged as a leading cathode for high energy density cells against a standard graphite anode. ${ }^{26,27}$ The voltage windows of both electrodes were determined by using a three-electrode cell with a lithium metal reference electrode (Fig. S3a). Figure 2a shows the voltage profile of the NWO/NMC cell (1.78 mAh cell capacity). At a $0.2 \mathrm{C}$ rate, it shows a discharge capacity of $175 \mathrm{mAh} \mathrm{g}^{-1}$ in the working voltage range of $1-3 \mathrm{~V}$, with $>91.6 \%$ of the capacity being accessed above $1.5 \mathrm{~V}$ and an initial coulombic efficiency of this NWO/NMC cell of $87.6 \%$ (Fig. S3b).

Figure $2 \mathrm{~b}$ shows the discharge capacity as a function of C-rate obtained from the NWO/NMC cell. At $0.2 \mathrm{C}$, the cell showed 

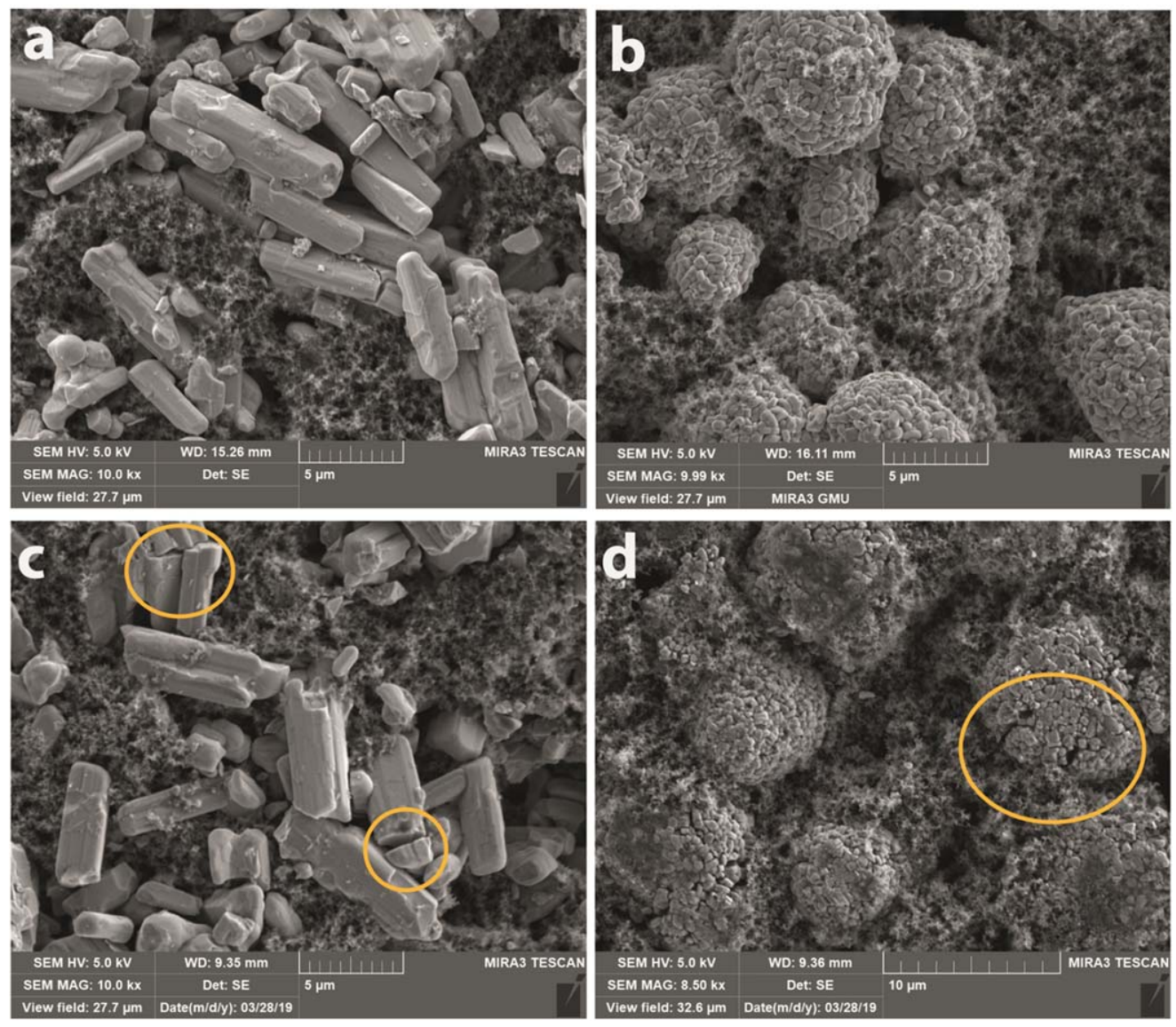

Figure 3. SEM images of the (a) pristine NWO, (b) pristine NMC, (c) 500 cycled NWO and d) 500 cycled NMC electrodes.
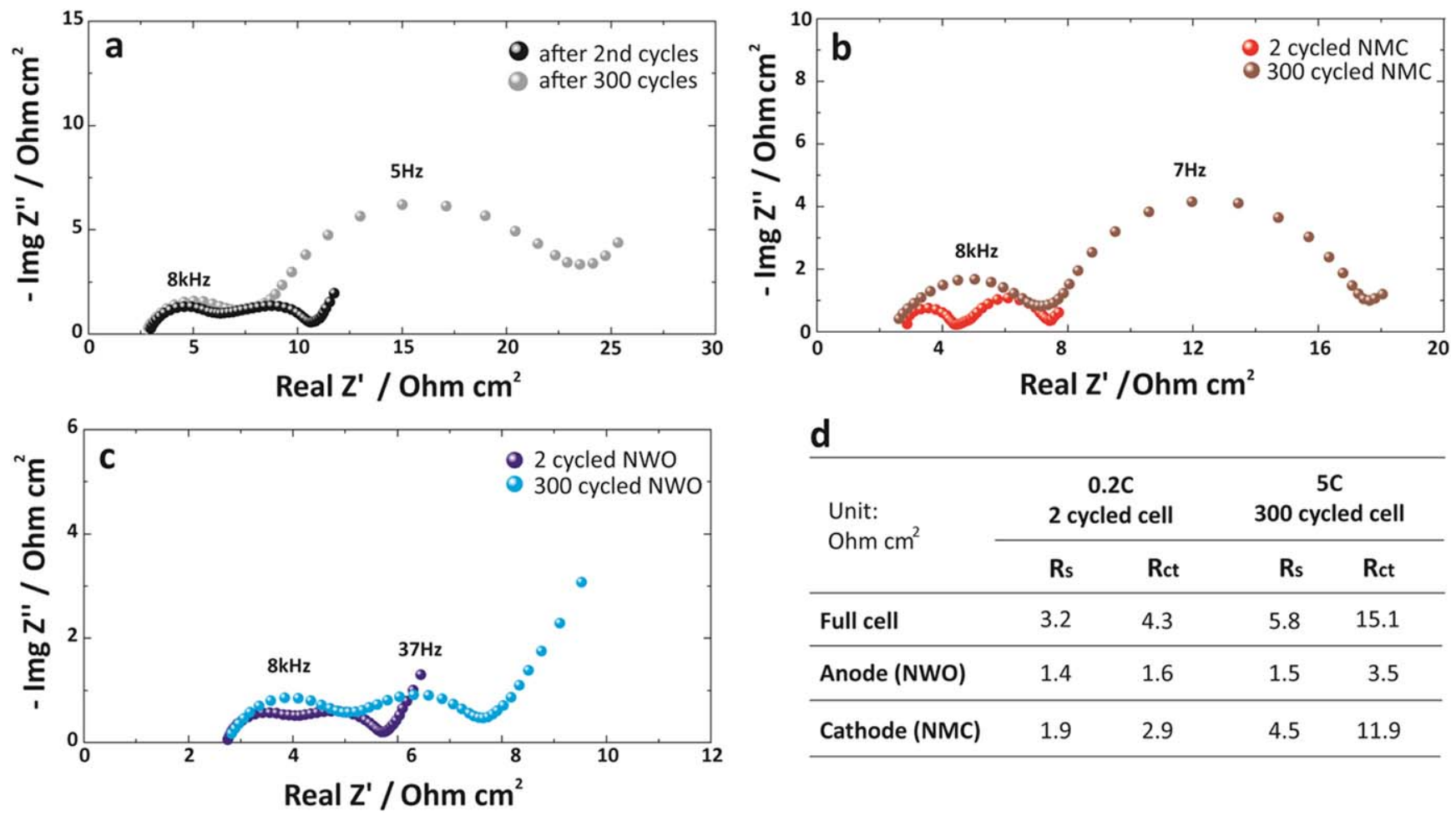

d

\begin{tabular}{lcccc}
\hline \multirow{2}{*}{$\begin{array}{l}\text { Unit: } \\
\text { Ohm cm }\end{array}$} & \multicolumn{2}{c}{$\mathbf{0 . 2 C}$} & \multicolumn{2}{c}{$\mathbf{5 C}$} \\
& \multicolumn{2}{c}{$\mathbf{2}$ cycled cell } & \multicolumn{2}{c}{$\mathbf{3 0 0}$ cycled cell } \\
\cline { 2 - 5 } & Rs & Rct & Rs & Rct \\
\hline Full cell & 3.2 & 4.3 & 5.8 & 15.1 \\
\hline Anode (NWO) & 1.4 & 1.6 & 1.5 & 3.5 \\
\hline Cathode (NMC) & 1.9 & 2.9 & 4.5 & 11.9 \\
\hline
\end{tabular}

Figure 4. Nyquist plots of the (a) full cell after the 2nd and 300th cycles at $2 \mathrm{~V}$ during charging step, and Nyquist plots of the (b) symmetric NMC cell and (c) symmetric NWO cell from the full cell electrodes. (d) Fitting results from measured impedance by using the equivalent circuit shown in Fig. S6. In this study, bulk resistance which is affected by electrolyte solution resistance in the cell is manually shifted to the same number as different separators (polymer separator and glass fiber separator) were used for the full cells and half cells, respectively. 

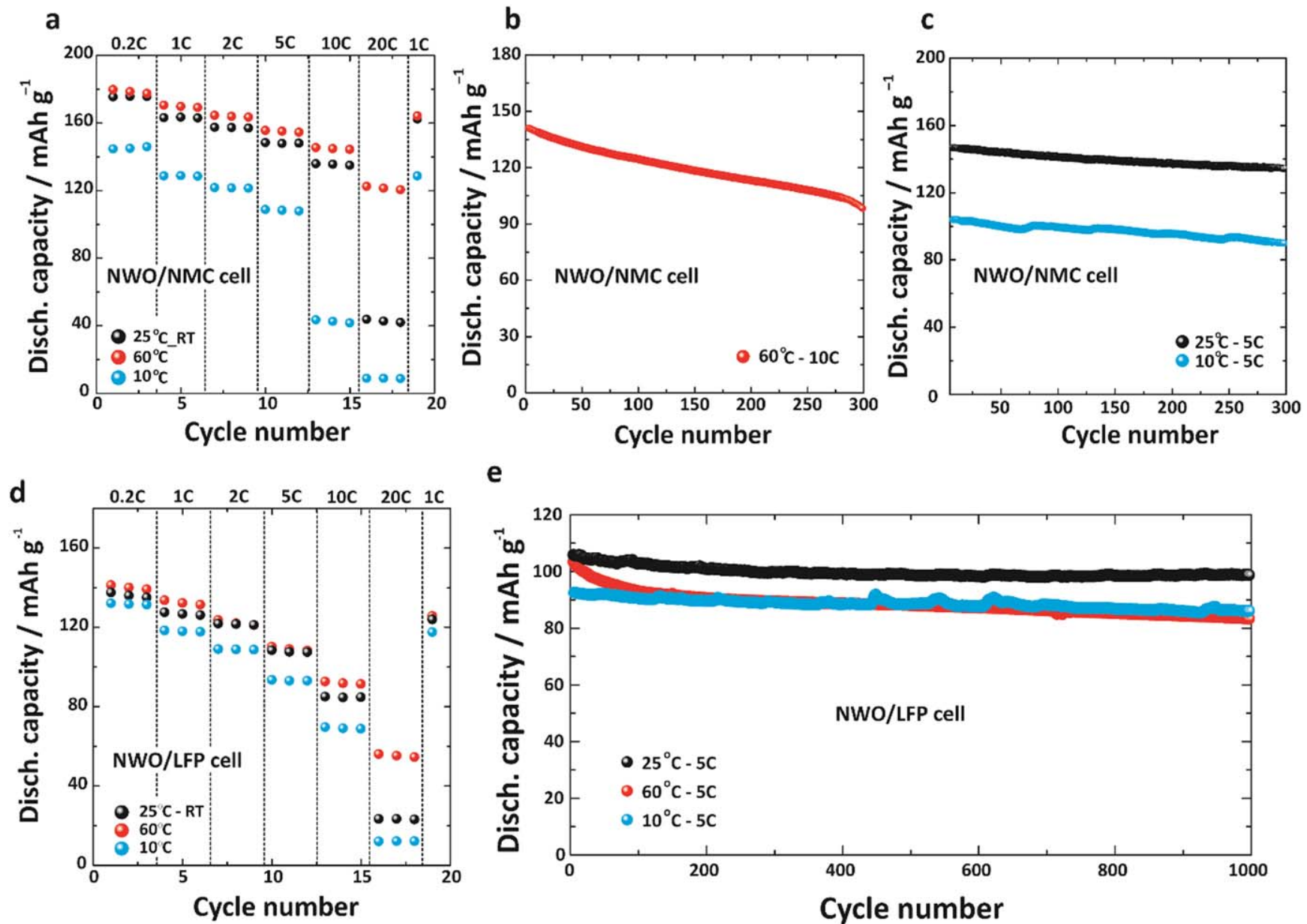

e

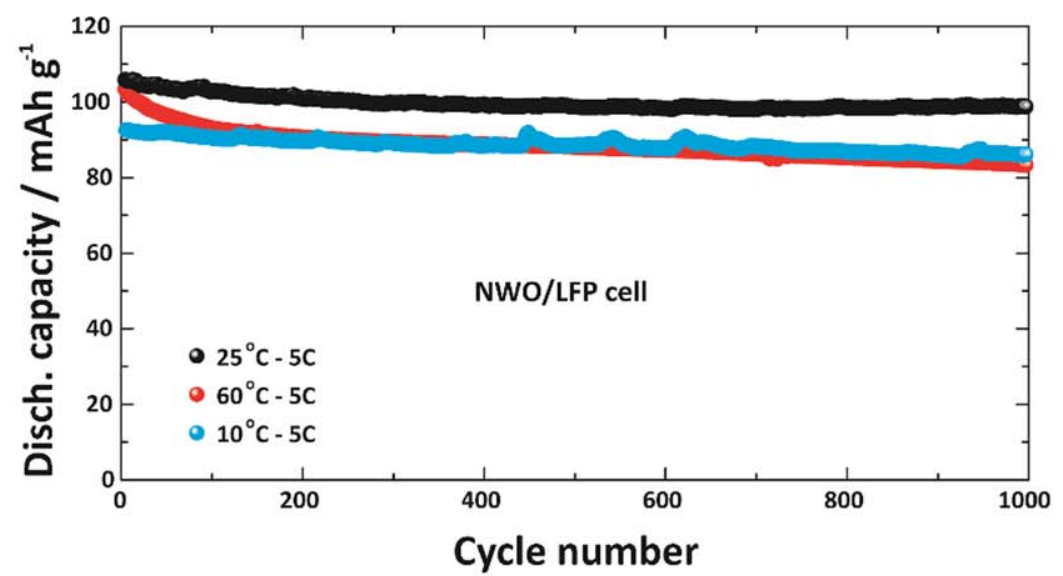

Figure 5. (a) Rate performance comparison as a function of the cell operation temperature $\left(10,25{ }^{\circ} \mathrm{C}\right.$ and $\left.60{ }^{\circ} \mathrm{C}\right)$. Long-term cycle performance of $\mathrm{NWO} / \mathrm{NMC}$ cell (b) at $60{ }^{\circ} \mathrm{C}$ and $10 \mathrm{C}$ rate and (c) at $10{ }^{\circ} \mathrm{C}$ and $25^{\circ} \mathrm{C}$ at $5 \mathrm{C}$ rate conditions. (d) Rate performance comparison of the NWO/LFP cells as a function of temperature and (e) long-term cycle performance at $10{ }^{\circ} \mathrm{C}, 25^{\circ} \mathrm{C}, 60{ }^{\circ} \mathrm{C}$ at $5 \mathrm{C}$ rate.

discharge capacity of $175 \mathrm{mAh} \mathrm{g}^{-1}$, with the successively decreasing capacities of $163,157,148$ and $136 \mathrm{mAh} \mathrm{g}^{-1}$ at $1 \mathrm{C}, 2 \mathrm{C}$, $5 \mathrm{C}$ and $10 \mathrm{C}$, respectively. A noticeable drop in capacity to $43 \mathrm{mAh} \mathrm{g}^{-1}$ was obtained upon $20 \mathrm{C}$ cycling. Similarly, to the LFP/NWO full cell, we attribute this drop to kinetic limitation in the electrode since i) close to the initial capacity $\left(162 \mathrm{mAh} \mathrm{g}^{-1}\right)$ could be recovered on returning to $1 \mathrm{C}$, and ii) $152 \mathrm{mAh} \mathrm{g}^{-1}$ at $20 \mathrm{C}$ is obtained for a full cell with a lower loading. Capacity retention and coulombic efficiency at $5 \mathrm{C}$ for 500 cycles were $86.8 \%$ and $99.9 \%$, respectively (Fig. 2c). This means a stable cycling performance with a $0.026 \%$ of capacity loss per cycle at a $5 \mathrm{C}$ rate operation.

To gain further insights into the structural changes and the possible sources of the degradation of the NWO/NMC full cell, ex situ XRD and SEM analyses were conducted on the extracted electrodes from the cells that were cycled 500 times over the full state-of-charge range. The XRD pattern from the cycled NWO electrode (Fig. 2c) shows no indication of any new phases; however, the monoclinic lattice has expanded by $1.2 \%$ in comparison to that of the pristine material, according to Rietveld refinements (Fig. S4 and Table SI), most likely because of the presence of $\mathrm{Li}^{+}$in the structure. ${ }^{17}$ On the NMC side (Fig. 2d), Rietveld refinement shows a shrinkage along the $a$ - and $b$-direction and an elongation along the $c$-direction compared to the pristine material, which is consistent with $\mathrm{Li}$ deficiency. ${ }^{28-31}$ Based on the volume changes, it can be proposed that, at the end of the 500th discharge, a quantity of lithium equivalent to $25 \mathrm{mAh} \mathrm{g}^{-1}$ has not been removed from NWO while $42 \mathrm{mAh} \mathrm{g}^{-1}$ is missing from the NMC (detailed in Table SI caption).
This suggests that the capacity loss is due to (i) active Li loss and (ii) accumulation of the $\mathrm{Li}$ in the NWO electrode.

To investigate the source of cell degradation further (NWO anode or NMC cathode), SEM images of the pristine and 500-cycled NWO anode are compared (Figs. 3a, 3c). The NWO particles having an elongated shape, due to a preferential growth of the crystal along the b direction, show several microcracks and a optically clean surface in both the pristine material and after cycling. On the other hand, SEM images (Figs. 3b, 3d) of the pristine and 500-cycled NMC cathodes demonstrate a clear partial destruction of the spherical particles. Particle cracking during cycling is a relatively well-known degradation phenomenon observed from NMC cathode materials; cracks on the particle surfaces can cause, or accelerate, the dissolution of transition metals such as $\mathrm{Mn}$ and $\mathrm{Ni}$. Furthermore, the electrical contact between the active material and the conductive carbon can be lost resulting in degradation of the cell performance. $^{29,30,32}$

Electrochemical impedance measurements were conducted in full cells and symmetric cells. Cell impedance was measured in symmetric cells which were assembled with electrodes taken from two full cells operated under the same conditions. Two sets of cells were prepared: one was tested after 2 cycles at $0.2 \mathrm{C}$ and the other was tested after 300 cycles at $5 \mathrm{C}$. Figure $4 \mathrm{a}$ indicates the full cell impedance obtained after the 2nd and 300th cycles; Figs. $4 \mathrm{~b}$ and $4 \mathrm{c}$ represent the cell impedance from cathode and anode symmetric cells, respectively. The data were fitted assuming an equivalent circuit $^{33}$ composed of the bulk resistance $\left(R_{b}\right)$, electrode surface 
a

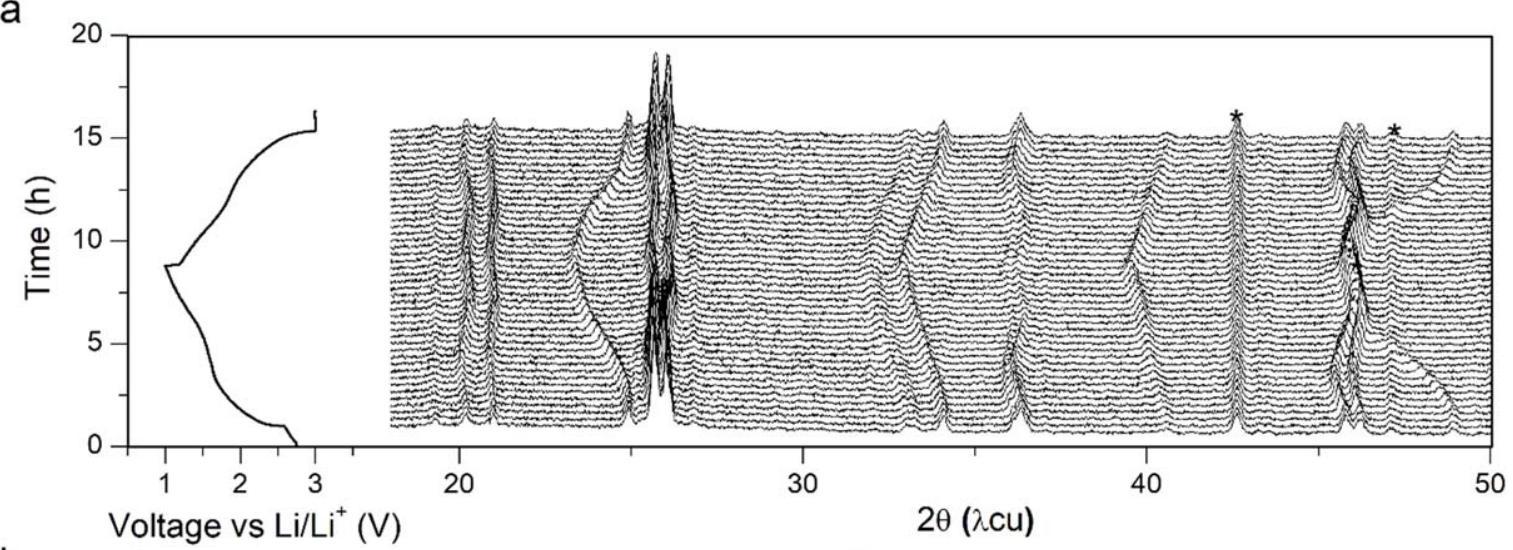

b

Voltage vs $\mathrm{Li} / \mathrm{Li}^{+}(\mathrm{V})$

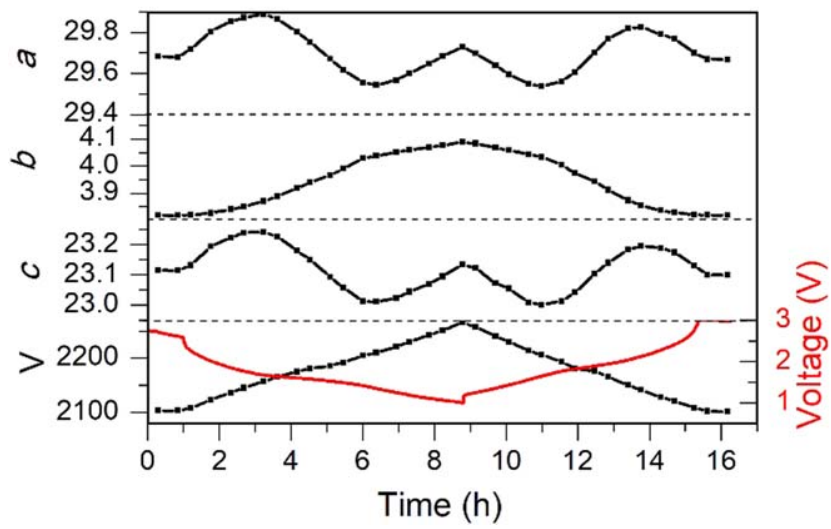

C

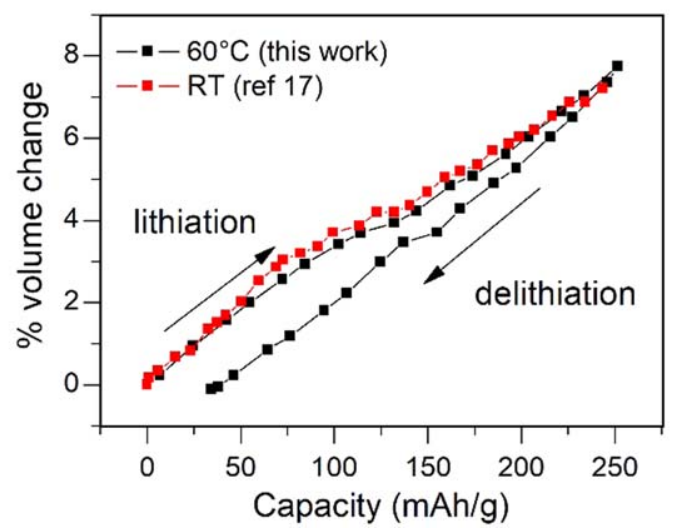

Figure 6. (a) XRD patterns obtained operando during the 1st cycle of a NWO half-cell at $60{ }^{\circ} \mathrm{C}$ and $\mathrm{C} / 5$ rate together with the galvanostatic profile on the left side. *beryllium window (b) Cell parameters in $\AA$ and unit cell volume in $\AA^{3}$ together with the galvanostatic cycling data obtained from Lebail fit of the operando data. (c) Variation of the unit cell volume at room temperature and $60{ }^{\circ} \mathrm{C}$ in red and black, respectively.
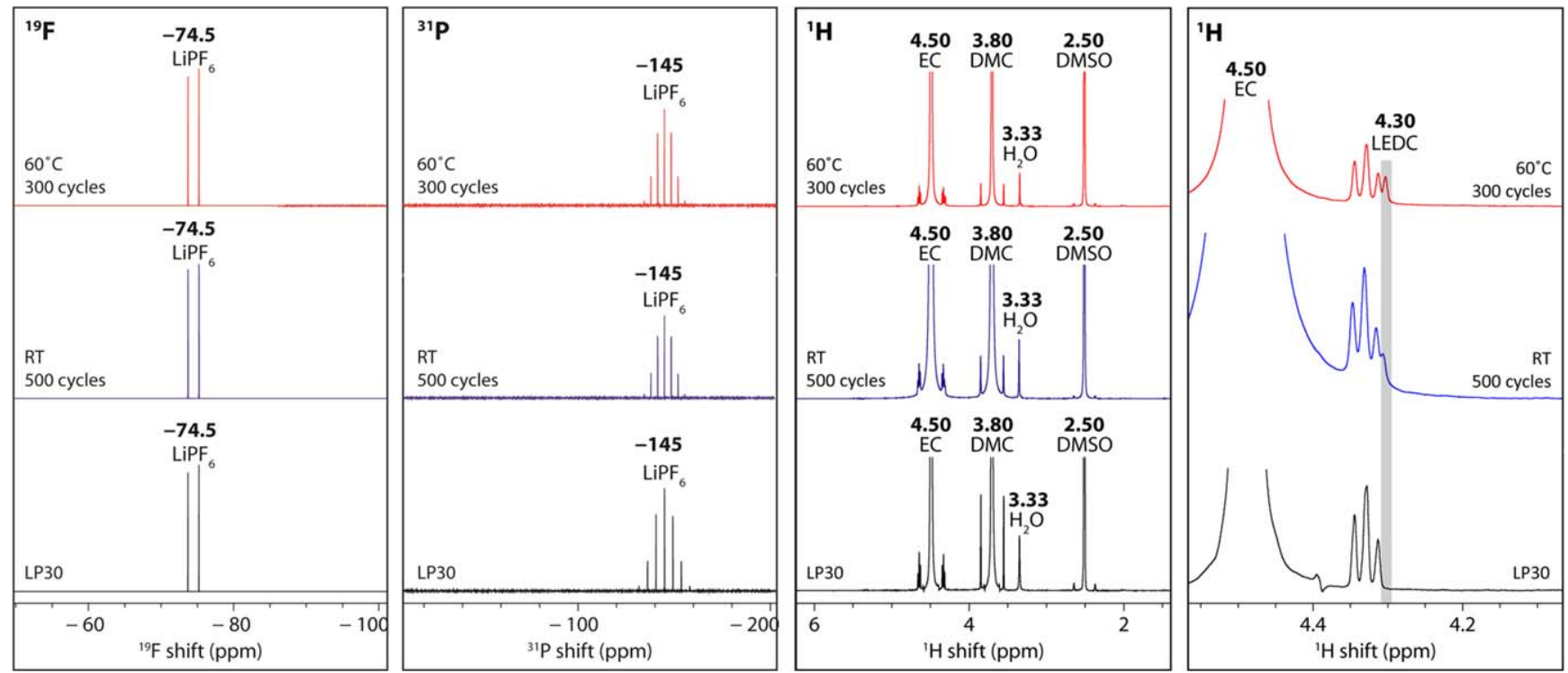

Figure 7. ${ }^{1} \mathrm{H},{ }^{19} \mathrm{~F},{ }^{31} \mathrm{P}$ solution NMR spectra of the electrolytes extracted from the cells (DMSO- $d_{6}$ solvent) cycled at a rate corresponding to $5 \mathrm{C}$ for 300 cycles at $60{ }^{\circ} \mathrm{C}$ and for 500 cycles at $25{ }^{\circ} \mathrm{C}$, and LP30 electrolyte as baseline. Note that the water peak likely originates from the DMSO solvent.

resistance $\left(R_{s}\right)$ and charge transfer resistance $\left(R_{c t}\right)$ as shown in Fig. S5; the fitted parameters are summarized in Fig. 4d. In a full cell, the increase in $\mathrm{R}_{\mathrm{ct}}$ upon cycling is the dominant source of the increase in overall cell impedance. By cycling the same electrode films in symmetric cells, the $\mathrm{R}_{\mathrm{ct}}$ in the NWO symmetric cell only increases from 1.6 to $3.5 \Omega \mathrm{cm}^{2}$ while $\mathrm{R}_{\mathrm{ct}}$ in the NMC symmetric cell increases from 2.9 to $11.9 \Omega \mathrm{cm}^{2}$. This indicates that the increase of the full cell resistance is mainly due to the increase in charge transfer resistance at the NMC cathode rather than at the NWO anode. Note that the increase of the charge transfer resistance at the 


\section{a. F1s}
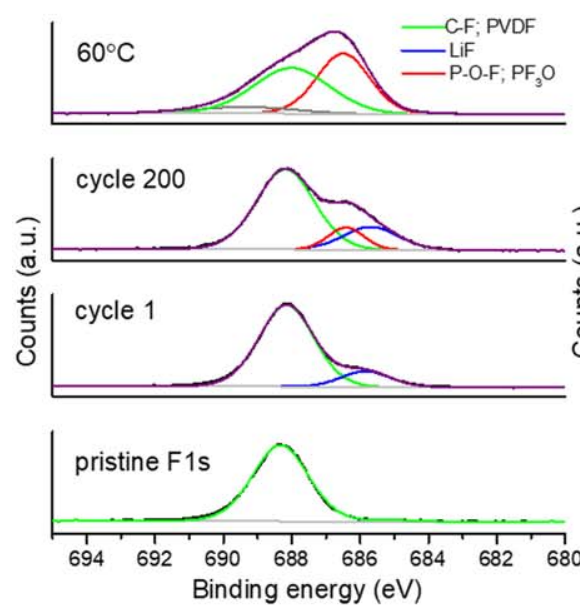

d. C1s
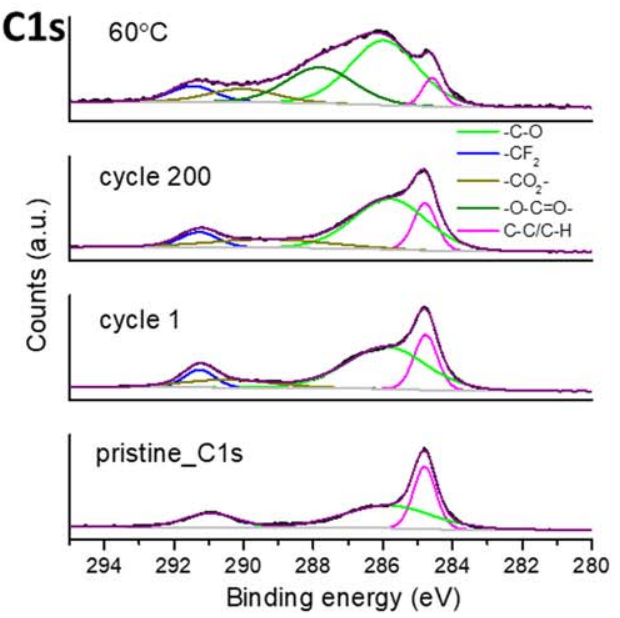

b. P2p
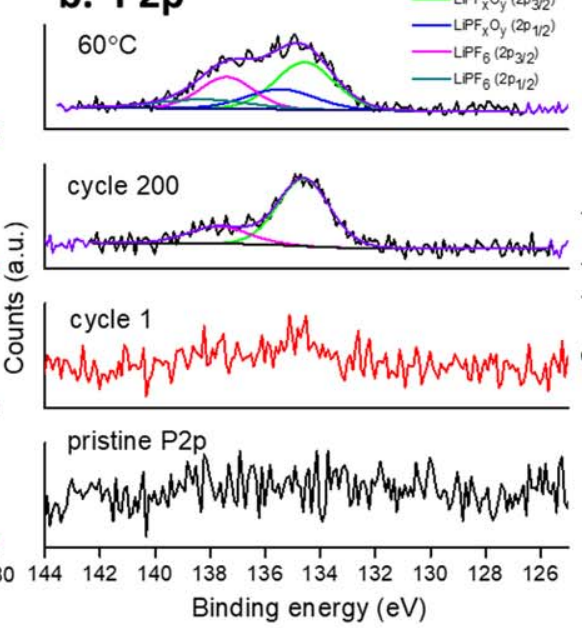
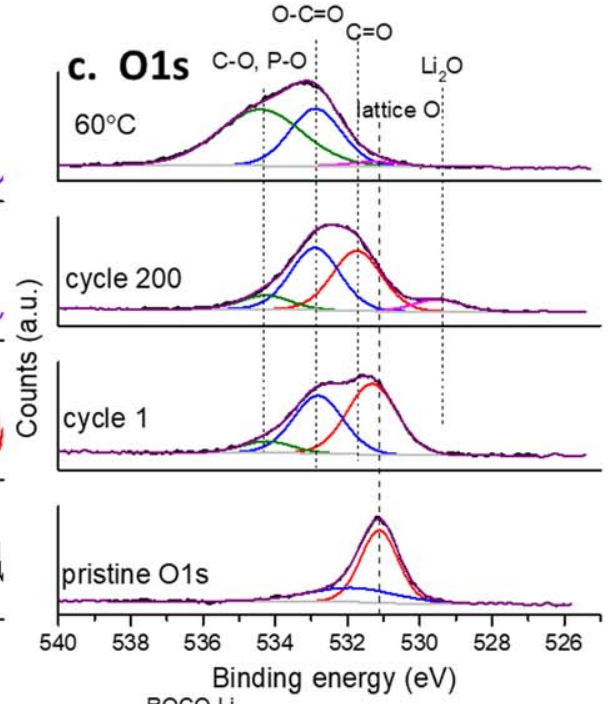

e. Li1s $\mathrm{ROCO}_{2} \mathrm{Li}$

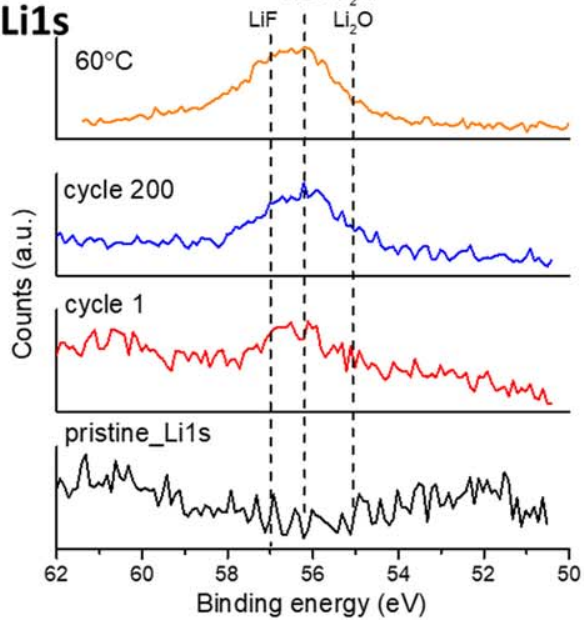

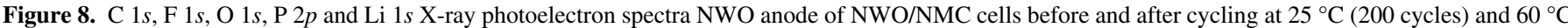
(300 cycles). The fitted and measured spectra are marked with purple and black, respectively.

NMC cathode is consistent with previous literature and explanations for this include a loss of electrical contact by particle fracture and/or the formation of a resistive surface layer. ${ }^{21,26,27}$

Temperature dependence of the NWO properties.-Next, in order to evaluate the performance of the cell at different temperatures, NWO/NMC and NWO/LFP cells were tested at $10{ }^{\circ} \mathrm{C}, 25{ }^{\circ} \mathrm{C}$ and $60{ }^{\circ} \mathrm{C}$ (Fig. 5). The discharge capacities of the two cells tested at different C-rates at $60{ }^{\circ} \mathrm{C}$ and $10{ }^{\circ} \mathrm{C}$ show higher and lower relative values, respectively, as compared to the $25^{\circ} \mathrm{C}$ cell, as expected from the thermal activation of the kinetics of charge transfer and diffusion. Long-term cycling performance of NWO/NMC was evaluated for 300 cycles under three different conditions: $10 \mathrm{C}$ rate at $60{ }^{\circ} \mathrm{C}$ (Figs. 5b) and $5 \mathrm{C}$ rate at $10^{\circ} \mathrm{C}$ and $25^{\circ} \mathrm{C}$ (Fig. 5c). Cell cycling at $60{ }^{\circ} \mathrm{C}(10 \mathrm{C}$ rate $)$ resulted in a loss of $30.8 \%$ of discharge capacity after 300 cycles while the cells at $25{ }^{\circ} \mathrm{C}(5 \mathrm{C}$ rate $)$ and $10^{\circ}$ C (5 C rate) showed $9.2 \%$ and $15.5 \%$ capacity loss in the same cycling window. Variable-temperature cycling of NWO/LFP was conducted for 1000 cycles at $5 \mathrm{C}$ rate. At temperatures of $10{ }^{\circ} \mathrm{C}$, $25{ }^{\circ} \mathrm{C}$ and $60{ }^{\circ} \mathrm{C}$ (Figs. 5e), 6.9\%, 7.9\% and $18.1 \%$ capacity losses were observed over 1000 cycles, respectively. This indicates NWO is suitable at different temperatures and that the NWO/LFP combination has better cycling stability and operational temperature range than NWO/NMC with the electrolyte used here.

Owing to the excellent cycling stability of the LFP/NWO full cell at $60{ }^{\circ} \mathrm{C}$, we conducted an operando $\mathrm{XRD}$ experiment at this temperature during the 1st cycle of a NWO half-cell at C/5 (Fig. 6a), and plotted the results of the Lebail refinements (Figs. 6b, 6c). A solid solution mechanism is observed across the full cycle, with an increase of the $b$ parameter and a more complex variation of the $a$ and $c$ parameters. Such evolution is very similar to the room temperature behaviour from Ref. 17, as shown in Fig. 6c in which the trace of the unit cell volume variation during $\mathrm{Li}$ insertion/extraction at $60{ }^{\circ} \mathrm{C}$ is nearly superimposed with the one recorded at $25{ }^{\circ} \mathrm{C}$. The similar structural evolution is consistent with the good cycling behaviour at $60{ }^{\circ} \mathrm{C}$ and also calls for the investigation of the temperature limit at which this material can cycle without structural decomposition.

Electrolyte degradation in NWO full cells.-To understand the degradation of the electrolyte during full cell cycling, NMR and XPS analyses were carried out to track the presence of dissolved and surface species, respectively.

${ }^{1} \mathrm{H},{ }^{19} \mathrm{~F}$ and ${ }^{31} \mathrm{P}$ NMR spectra of the electrolyte extracted from NWO/NMC cells cycled at $5 \mathrm{C}$ for 300 cycles at $60{ }^{\circ} \mathrm{C}$ and 500 cycles at $25{ }^{\circ} \mathrm{C}$ are compared to the spectra of a pristine electrolyte (Fig. 7). On the ${ }^{19} \mathrm{~F}$ and ${ }^{31} \mathrm{P}$ spectra no extra peaks are observed after cycling. The ${ }^{1} \mathrm{H}$ spectra of the cycled samples present a small peak at $4.3 \mathrm{ppm}$ originating from trace quantities of lithium ethylene dicarbonate (LEDC) likely due to hydrolysis of EC with trace moisture. Integration of the ${ }^{1} \mathrm{H}$ peak area gives an estimated content of LEDC:EC as $0.1 \mathrm{~mol} \%$ (300 cycles, $60{ }^{\circ} \mathrm{C}$ ) and $0.05 \mathrm{~mol} . \%$ (500 cycles, $25^{\circ} \mathrm{C}$ ). 
$\mathrm{F} 1 s, \mathrm{C} 1 s, \mathrm{O} 1 s, \mathrm{Li} 1 s$ and $\mathrm{P} 2 p$ photoelectron spectra of NWO anode from cycled NWO/NMC cells (Fig. 8) show the presence of surface species after cycling at room temperature (200 cycles) as well as $60{ }^{\circ} \mathrm{C}$ (300 cycles). The $\mathrm{F} 1 s$ spectra show that $\mathrm{LiF}$ forms after the 1 st cycle but does not change significantly after 200 cycles (Fig. 8a). However, a new peak appears around $686.4 \mathrm{eV}$ due to $\mathrm{PO}_{\mathrm{x}} \mathrm{F}_{\mathrm{y}}$ species after 200 cycles, presumably arising from the degradation of $\mathrm{LiPF}_{6}$ via reaction with moisture or oxygen. ${ }^{34,35}$ Formation of $\mathrm{PO}_{\mathrm{x}} \mathrm{F}_{\mathrm{y}}$ species is also confirmed by $\mathrm{P} 2 p$ spectra ${ }^{36}$ after cycling at room temperature (Fig. 8b). On cycling at $60{ }^{\circ} \mathrm{C}$, the extent of $\mathrm{LiPF}_{6}$ degradation has increased, as seen by a significant rise in both the $\mathrm{F} 1 s$ and the $\mathrm{P} 2 p$ XPS intensity due to $\mathrm{PO}_{\mathrm{x}} \mathrm{F}_{\mathrm{y}}$ components. In addition, the $\mathrm{O} 1 \mathrm{~s}$ spectra for the $60{ }^{\circ} \mathrm{C}$ cycled sample shows a large increase in peak intensity at $534.4 \mathrm{eV}$ arising from singly-bonded oxygen moieties, including $\mathrm{P}-\mathrm{O}$ species $^{37}$ (Fig. 8c). The $\mathrm{C} 1 s$ and $\mathrm{O} 1 s$ spectra show that the increase in intensity of $\mathrm{C}-\mathrm{O}$ and $\mathrm{C}=\mathrm{O}$ species at the end of cycling could be due to the accumulation of alkyl carbonate and lithium carbonate species (Figs. 6c and 6d). C $1 s$ XPS of the $60{ }^{\circ} \mathrm{C}$ cycled sample shows an intense peak around $288.9 \mathrm{eV}$ assigned to $\mathrm{O}-\mathrm{C}=\mathrm{O}$ bonds, ${ }^{36}$ likely to be originating from lithium ethylene dicarbonate (LEDC) as also observed in the NMR studies. Li $1 s$ shows a broad band from $54-58 \mathrm{eV}$ that includes contributions from $\mathrm{LiF}$ and $\mathrm{ROCO}_{2} \mathrm{Li}$ surface species (Fig. 8e). ${ }^{36} \mathrm{~A}$ trace amount of $\mathrm{Li}_{2} \mathrm{O}$ is detected by $\mathrm{O} 1 s$ and Li $1 s$ spectra after long-term cycling at room temperature.

Overall, it can be concluded that i) a very small amount of EC is being reduced at the NWO surface leading to a trace amount of LEDC in the electrolyte and the accumulation of lithium alkyl carbonate at the surface of electrode, ii) residual water leads to the formation of $\mathrm{LiPF}_{6}$ decomposition products such as deposited $\mathrm{PO}_{\mathrm{x}} \mathrm{F}_{\mathrm{y}}$ species and soluble $\left[\mathrm{PO}_{2} \mathrm{~F}_{2}\right]^{-} \cdot{ }^{38,39}$ This suggests only minor electrolyte decomposition even in the absence of additives.

\section{Conclusions}

This work demonstrates the feasibility of utilizing NWO anodes with two commercial cathodes (LFP, NMC-622) for Li-ion batteries; it also represents a step forward in terms of finding the optimum cell components (cathode, electrolyte) to fully realize the high-rate electrochemical capabilities of NWO. NWO/LFP cells show an $88.9 \%$ capacity retention at $10 \mathrm{C}$ rate for 1000 cycles and $\mathrm{NWO} /$ NMC cells show $86.8 \%$ capacity retention at $5 \mathrm{C}$ rate for 500 cycles. Even at $10{ }^{\circ} \mathrm{C}$ and $60{ }^{\circ} \mathrm{C}$, NWO/NMC cells operate well up to $5 \mathrm{C}$ rate and $20 \mathrm{C}$ rate, respectively. The slight degradation of the cell performance that does occur mainly comes from the degradation of NMC cathodes, as shown from the cell impedance measurements. The stable and fast electrochemical performance shown here by anodes with bulk NWO particles, shows that these cells represent feasible and promising candidates for high rate lithium ion batteries.

\section{Acknowledgments}

This work was supported by EPSRC via the LIBATT grant (EP/ M009521/1) and via an Impact Acceleration Account Follow-On grant (EP/R511675/1). The X-ray photoelectron (XPS) data collection was performed at the EPSRC National Facility for XPS ("HarwellXPS"), operated by Cardiff University and UCL, under Contract No. PR16195. We thank S. Shivareddy from CB2Tech Ltd. for advice on variable temperature cell operation. CPG and KJG are shareholders of a company that aims to commercialise fast charging anode materials.

\section{ORCID}

Yumi Kim (D) https://orcid.org/0000-0001-6675-7522

Quentin Jacquet (D) https://orcid.org/0000-0002-3684-9423

Kent J. Griffith (D) https://orcid.org/0000-0002-8096-906X

\section{References}

1. M. Li, J. Lu, Z. Chen, and K. Amine, Adv. Mater., 30, 1800561 (2018).

2. N. Nitta, F. Wu, J. T. Lee, and G. Yushin, Mater. Today, 18, 252 (2015).

3. S. Goriparti, E. Miele, F. De Angelis, E. Di Fabrizio, R. Proietti Zaccaria, and C. Capiglia, J. Power Sources, 257, 421 (2014)

4. K. Kang, Y. S. Meng, J. Bréger, C. P. Grey, and G. Ceder, Science, 311, 977 (2006)

5. S. W. Lee, N. Yabuuchi, B. M. Gallant, S. Chen, B.-S. Kim, P. T. Hammond, and Y. Shao-Horn, Nat. Nanotechnol., 5, 531 (2010).

6. A. Kraytsberg and Y. Ein-Eli, Adv. Energy Mater., 2, 922 (2012).

7. B. Scrosati and J. Garche, J. Power Sources, 195, 2419 (2010).

8. B. Wang, W. A. Abdulla, D. Wang, and X. S. Zhao, Energy Environ. Sci., 8, 869 (2015).

9. F. Lin, I. M. Markus, D. Nordlund, T.-C. Weng, M. D. Asta, H. L. Xin, and M. M. Doeff, Nat. Commun., 5, 3529 (2014).

10. P. Rozier and J. M. Tarascon, J. Electrochem. Soc., 162, A2490 (2015).

11. V. A. Agubra and J. W. Fergus, J. Power Sources, , 268, 153 (2014).

12. S. An, J. Li, C. Daniel, D. Mohanty, S. Nagpure, and D. L. Wood III, Carbon, 105, 52 (2016).

13. G.-N. Zhu, H.-J. Liu, J.-H. Zhuang, C.-X. Wang, Y.-G. Wang, and Y.-Y. Xia, Energy Environ. Sci., 4, 4016 (2011).

14. I. Belharouak, G. M. Koenig, and K. Amine, J. Power Sources, 196, 10344 (2011)

15. Y.-B. He et al., Sci. Rep., 2, 913 (2012).

16. I. Belharouak, G. M. Koenig, T. Tan, H. Yumoto, N. Ota, and K. Amine, J. Electrochem. Soc., 159, A1165 (2012).

17. K. J. Griffith, K. M. Wiaderek, G. Cibin, L. E. Marbella, and C. P. Grey, Nature, 559, 556 (2018).

18. C. Yang et al., J. Power Sources, 360, 470 (2017).

19. L. Yan, H. Lan, H. Yu, S. Qian, X. Cheng, N. Long, R. Zhang, M. Shui, and J. Shu, J. Mater. Chem. A, 5, 8972 (2017)

20. Q. Cheng, J. Liang, N. Lin, C. Guo, Y. Zhu, and Y. Qian, Electrochim. Acta, 176 456 (2015).

21. B. Guo, X. Yu, X.-G. Sun, M. Chi, Z.-A. Qiao, J. Liu, Y.-S. Hu, X.-Q. Yang, J. B. Goodenough, and S. Dai, Energy Environ. Sci., 7, 2220 (2014).

22. J. Rodríguez-Carvajal, Physica B, 192, 55 (1993).

23. E. Pohjalainen, T. Rauhala, M. Valkeapää, J. Kallioinen, and T. Kallio, J. Phys. Chem., 119, 2277 (2015).

24. W. Wang, D. Choi, and Z. Yang, Metall. Mater. Trans. A, 44A, S21 (2013).

25. C. Wang et al., Chem. Mater., 27, 5647 (2015).

26. G. E. Blomgren, J. Electrochem. Soc., 164, A5019 (2017)

27. G. Zubi, R. Dufo-López, M. Carvalho, and G. Pasaoglu, Renew. Sust. Energ. Rev., 89, 292 (2018).

28. J. Li, L. E. Downie, L. Ma, W. Qiu, and J. R. Dahn, J. Electrochem. Soc., 162, A1401 (2015).

29. P.-C. Tsai, B. Wen, M. Wolfman, M.-J. Choe, M. S. Pan, L. Su, K. Thornton, J. Cabana, and Y.-M. Chiang, Energy Environ. Sci., 11, 860 (2018).

30. M. Ebner, F. Geldmacher, F. Marone, M. Stampanoni, and V. Wood, Adv. Energy Mater., 3, 845 (2013)

31. I. Buchberger, S. Seidlmayer, A. Pokharel, M. Piana, J. Hattendorff, P. Kudejova, R. Gilles, and H. A. Gasteiger, J. Electrochem. Soc., 162, A2737 (2015).

32. P. Yan, J. Zheng, M. Gu, J. Xiao, J.-G. Zhang, and C.-M. Wang, Nat. Commun., 8, $14101(2017)$

33. S. S. Zhang, K. Xu, and T. R. Jow, Electrochim. Acta, 49, 1057 (2004).

34. G. M. Veith and N. J. Dudney, J. Electrochem. Soc., 158, A658 (2011).

35. H. Ota, X. Wang, and E. Yasukawa, J. Electrochem. Soc., 151, A437 (2004).

36. D. Aurbach, B. Markovsky, A. Shechter, Y. E. Eli, and H. Cohen, J. Electrochem. Soc., 143, 3809 (1996).

37. N. Schulz, R. Hausbrand, C. Wittich, L. Dimesso, and W. Jaegermann, J. Electrochem. Soc., 165, A833 (2018).

38. B. S. Parimalam, A. D. MacIntosh, R. Kadam, and B. L. Lucht, J. Phys. Chem., 121, 22733 (2017)

39. M. Stich, M. Göttlinger, M. Kurniawan, U. Schmidt, and A. Bund, J. Phys. Chem., 122, 16 (2018) 